\title{
Model Hukum Islam: Suatu Konsep Metode Penemuan Hukum melalui Pendekatan Ushuliyyah
}

\author{
Yusna Zaidah \\ Universitas Islam Negeri Antasari Banjarmasin \\ e-mail: yusnazaidah@,uin-antasari.ac.id
}

\begin{abstract}
This research will discuss about method of discovery of Islamic law through ushul approach. In an effort to find the law unearthed from its source, the multipliers of Islamic law should start from the principle of benefit to the method offered by the preceding experts. So found maslahah method, istibsan, linguistic approach, and method of causation.
\end{abstract}

Keywords: Method, maslahat, qiyas, language, law, ushul

\begin{abstract}
Abstrak: Penelitian ini akan membahas mengenai metode penemuan hukum islam melalui pendekatan ushul. Dalam upaya menemukan hukum yang digali dari sumbernya, para pengali hukum Islam seyogianya bertitik tolak dari prinsip kemaslahatan dengan metode yang telah ditawarkan oleh para pendahulu yang ahli dibidangnya. Maka ditemukan metode maslahah, istibsan, pendekatan linguistik, dan metode kausasi.
\end{abstract}

Kata kunci: Metode, maslahat, qiyas, bahasa, bukum, ushul

\section{Pendahuluan}

Menurut para ahli ushul figh, hukum Islam merupakan instruksiwacana (khitab) Allah kepada para hamba-Nya. Sebagai khitāa, manusia hanya bertugas mengenali dan menemukannya melalui tanda-tanda yang diberikan Allah. Dengan kata lain, hukum syari'ah merupakan mandiscovered law dan bukan man-made law. ${ }^{1}$ 
Hal ini, tampak dalam ungkapan hanya berfungsi sebagai sumber Coulson, Tuhan yang merencanakan, hukum penjelas atau pemberita manusia yang memformulasikannya. ${ }^{2} \quad$ (mukbbir) tentang hukum Allah. ${ }^{4}$ Dengan demikian dapat dipahami, Dalam upaya menemukan bahwa hukum tidak selalu merupakan barang siap pakai, melainkan harus dicari dan ditemukan. Oleh karena itu, penemuan hukum merupakan suatu hal yang inheren dalam setiap sistem hukum, termasuk hukum Islam. Dan menemukan hukum haruslah dari sumber hukum itu sendiri.

Membicarakan sumber hukum merupakan merupakan persoalan polemik antara ahli ilmu tasauf dan ahli fiqih. Menurut Juhaya S. Praja ${ }^{3}$, ahli Tasauf berpendapat bahwa sumber hukum Islam, secara hakiki adalah Allah, sementara ahli fiqh berpendapat bahwa sumber hukum Islam itu adalah Quran sebagai dalil hukum. Al Ghazali berpendapat bahwa yang dimaksud dengan sumber utama adalah al qur'an, sementara as Sunnah sekalipun sifatnya wahyu,

Metodologi Hukum Islam (Kumpulan makalah tidak diterbitkan), h. 113

2 Noel J. Coulson, Konflik dalam Yurisprudensi Islam, ter. Fuad (Yogyakarta: Navila, 2001), h. 2.

3 Dedy Supriyadi, Sejarah Hukum Islam, Pustaka setia Bandung, 2010, h. 137
${ }_{4} \mathrm{Al}$ Ghazali, tt, Ibya Ulumuddin, Jilid I, Darl Fikr, Beirut, tt. h. 100 
metode yang mereka temukan, seperti pemahaman hukum yang terdapat dalam teks hukum dikaji dengan dengan metode hermeneutika maupun dari segi bahasanya yang disebut Ushul Fiqh.

Dengan demikian dapat dipahami bahwa ushul fiqh adalah ilmu yang terdiri dari aturan aturan umum untuk membantu para mujtahid untuk memecahkan permasalahan permasalahan agama baik untuk masa dahulu, sekarang maupun yang akan datang. Jadi, dapat dikatakan bahwa tidak mungkin orang dapat sampai pada kesimpulan fikih kalau ia tidak mengetahui ilmu Ushul Fiqh ini. Jika dilihat tujuan mempelajari Ushul Fiqh maka kata kunci yang paling penting dalam mempelajari ilmu tersebut adalah agar dapat mengetahui dan mempraktekkan kaidah-kaidah cara mengeluarkan hukum dari dalilnya.

Jumhur ulama sepakat bahwa obyek kajian ilmu ushul fiqh adalah kaidah - kaidah atau metode istinbat hukum. Di dalam ilmu Ushul Fiqh dirumuskan metode memahami hukum Islam dan memahami dalildalil hukum yang mana dengan dalil- dalil tersebut dibangun hukum Islam yang ketentuan hukumnya sesuai dengan akal sehat (a reasionable assumption).

Imam Syafiei adalah orang yang mempunyai jasa dan andil yang besar sebagai pendiri atau guru arsitek ushul figh dalam kitabnya ar Risalah yang tidak hanya karya pertamanya membahasa Ushul Fiqh, tetapi juga sebagai model bagi ahli-ahli hukum dan para teorisasi yang muncul. Imam Syafi'i, ${ }^{5}$ adalah orang pertama kali mengembangkan Usbul Fiqh dan ia disebut sebagai inspirator yang berjasa besar atas bersatunya dua kelompok fiqh sebelum kedatangannya, yakni ahlul hadis (yakni aliran fikih yang berpegang pada makna tekstual nash) dan ablul-ra'yi (aliran fikih yang melihat substansi dan maksudmaksud nash). Imam Syafi'i juga disebut sebagai pendiri metode Iștinbāt (deduction) dalam penyusunan kaidah-kaidah Ushul fiqh. Coulson

5 Abd al-'Azīm al-Dî̀, Fiqh Imām Haramayn, (Qatar: Idārat Uhyā' al-Turāth alIslāmî, 1985), h. 36 
menjulukinya sebagai "The Mașter Architect" . 6

Hasil pemikiran Imam Syafi'i di bidang metodologi ini dianggap yang pling mencakup dan sistematis pada masanya., karena itu sampai batas tertentu dianggap sebagai koreksi dan penyempurnaan atas kaidah kaidah yang disusun dan digunakan oleh Imam Abu Hanifah (150 H/767 M) dan Imam Malik (179 H/795 M) dan ulama lain pada masa itu,Kaidah kaidah ini pada masa belakangan dilengkapi dan disempurnakan lagi, terutama sekali oleh ulama generasi al Ghazali (abad kelima Hijriah) dan setelah itu generasi Fakhrs al Din al Razi (abad ke enam $\mathrm{H}$ ), sehingga di tangan mereka ini dianggap baku dan sempurna. $^{7}$

Beranjak dari hal hal di atas penulisan ini akan mencoba membahas:

1. Apa yang dimaksud dengan teori/metode

6 N.J. Coulson, A Hiștory of Ișlamic Law, (Edinburg: Edinburg University Press, 1978), h. 53.

7 Al Yasa Abu Bakar, Metode Istislahiah, (Pemanfatan Ilmu Pengetahuan dalam Ushul Fiqh), Kencana, Jakarta, 2016, h. 9. penemuan hukum

Islam?

2. Apa saja bentuk teori/metode penemuan hukum Islam?

\section{Pengertian Teori/Metode}

\section{Penemuan Hukum Islam}

Dalam istilah ilmu Ushul Fikih teori atau metode penemuan hukum dipakai dengan istilah "istinbath"/thuruq al-istinbath yaitu cara-cara yang ditempuh seorang mujtahid dalam mengeluarkan hukum dari dalilnya ${ }^{8}$. Dengan demikian istinbath adalah cara bagaimana memperoleh ketentuan Hukum Islam dari dalil-dalilnya sebagaimana dibahas dalam ilmu Ushul Fiqh. Beristinbath hukum dari dalil-dalilnya dapat dilakukan dengan jalan pembahasan bahasa yang dipergunakan dalam dalil Al-Quran atau Sunnah Rasul, dan dapat pula dilakukan dengan jalan memahami jiwa hukum yang terkandung dalam dalilnya, baik yang menyangkut latar belakang yang menjadi landasan

${ }^{8}$ Asjmuni A. Rahman, Metode Penetapan Hukum Islam, Cet. 2, (Jakarta :PT. Bulan Bintang, 2004), hlm. 1. 
ketentuan hukum ataupun yang menjadi tujuan ketentuan hukum

Kajian metode penemuan hukum Islam ini ada yang menyebutnya dengan istilah metode hukum Islam biasanya berkenaan dengan teori klasik tentang sumber hukum Islam, baik di kalangan ahli hukum Islam maupun para pakar hukum Barat. ${ }^{10}$ Oleh karena itu fungsi dan sifat sutu metode tidak dapat dipisahkan, bahkan dipengruhi sifat sifat sumber hukum itu sendiri. Fakta historis menunjukkan bahwa pemahaman hukum Islam yang jelas ditempuh para sahabat Nabi telah mampu memberi peran penting dalam menampakkan karakteristik hukum Islam yang dinamis dan elastis seiring dengan tuntutan zaman yang dihadapi. Pembahasan metode dan sumber hukum ini terasa semakin penting dikemukakan karena selama ini masih terdapat diskursus sekitar penempatan ijma, qiyas, istihsan dan lainnya sebgai dalil hukum Islam pada

9 Ahmad Azhar Basyir, Pokok-Pokok Persoalan Filsafat Hukum Islam, (Yogyakarta, UII Pres, 1984), hlm.32

10 Qadhi Abu Hasan An Nubahi, Al Marqabah al UlyaFiman Yastabiq al Qadla wa al fitja, Kairo; Dar al Kitab al Misri, 1948, h. 20. satu sisi dan sebagi metode hukum pada sisi lainnya ${ }^{11}$.

Konsep penemuan hukum merupakan teori hukum terbuka yang pada pokoknya bahwa suatu aturan yang telah dimuat dalam ketentuanketentuan hukum yang ada dalam alQuran dan al-Hadis serta hukum postif (baca ; undang-undang, qanun dan fiqh) dapat saja dirubah maknanya, meskipun tidak ada diubah kata-katanya guna direlevasikan dengan fakta konkrit yang ada. Keterbukaan sistem hukum karena terjadi kekosongan hukum, baik karena belum ada undang-undangnya maupun undang-undang tidak jelas.

\section{Bentuk Teori Penemuan Hukum Islam}

Dalam hukum Islam, para juris muslim telah mengembangkan model penemuan hukum secara seksama guna menterjemahkan hukum Islam dalam realitas kehidupan. Model penemuan hukum dapat dilakukan dengan menggunakan kaidah-kaidah bahasa (lingkuistik) maupun dengan menggunakan kaidah-kaidah

11 Dedy Supriyadi, Sejarah Hukum Islam, 2010., h. 140 
Ushuliyah lainnya. Ahli Ushul Fiqh menetapkan ketentuan bahwa untuk mengeluarkan hukum dari dalilnya harus terlebih dahulu mengetahui kaidah syari'ah dan kaidah lughawiyah ${ }^{12}$.

Ali Yasa Abu Bakar berpendapat bahwa harus dibedakan antara dalil dan metode. Dalil menurutnya adalah hanya al Qur'an dan as Sunnah (dalil al munsyi') sedangkan dalil selebihnya (dalil al muzhhir) dianggap sebagai metode, yang dikelompokkan menjadi :

1) Metode lughawiyyah (penalaran yang bertumpu pada kaidah kaidah kebahasaan)

2) Metode Ta'liliyyah (pertimbangan yang bertumpu pada ilat (rasio legis)

3) Metode istishlabiyyah (pertimbangan yang bertumpu pada kemashlatan atau tujuan pensyariatan. ${ }^{13}$

Senada dengan hal tersebut Salam Mazkur menyebutkan bahwa bentuk bentuk metode hukum Islam

12 A.Djazuli, Ilmu Figh Penggalian, Perkembangan dan Penerapan Hukum Islam, Cet. 5, Edisi Revisi, Jakarta, Prebada Media, 2005), h.17

13 Ali Yasa Abu Bakar, Metode Istislahiah, 2016, , h. 18. bergantung pada landasan yang dipergunakan dalam berijtihad atau beristinbah, Menurutnya berdasarkan penelusuran terhadap ijtihad para sahabat terdapat tiga model pemikiran hukum (ijtihad), yakni ijtihad bayani, ijtihad qiyasi dan ijtihad istislabi. ${ }^{14}$

Ketiga model ijtihad tersebut dalam telaah Juhaya S. Praja tampaknya di kategorekan dalam dua metode, yaitu metode naqliyah (metode bayani) dan metode aqliyah metode qiyasi dan istislahi). Pengelompokan ini didasarkan kepada karakter sumber hukum Islam sendiri yang merupakan gabungan antara wahyu Allah dan ijtihad manusia. ${ }^{15}$

\section{Ijtihad Bayani}

Ijtihad ini berusaha menjelaskan makna makna nash yang masih memerlukan kejelasan (mujmal). ${ }^{16}$ Ketika para fukaha berbicara tentang sebuah dalil dari al Qur'an dan as Sunnah, sebenarnya yang mereka maksudkan adalah keputusan hukum yang digali dari ungkapan khusus

${ }^{14}$ Muhammad Salam Mazkur, Al Ijtihad fi Tasyri al Islami, Kairo: Dar an Nahdah al Arabiyah, 1984, h. 42-45

15 Juhaya S. Praja, h. 51-62.

16 Dedy Supriadi, Sejarah..., 2010., h. 
suatu ayat atau hadis, berdasarkan salah satu kategori ungkapan bahasa. Ungkapan atau istilah dikategorikan menurut hubungan dikenal dengan kejelasan (wuduh)), implikasi (dilalah), dan cakupan (syumul). ${ }^{17}$

Pada dalil dalil linguistic (bayani) berbasis nas, yakni berdasarkan implikasi (dilalat) yang termuat oleh terma terma tersebut. memunculkan empat kategori penunjukan makna (aldalalah). Menurut Jaser Audah ada dua klasifikasi yang sangat mirip yang disahkan oleh semua mazhab, sekalipun dalam istilah istilah yang berbeda tipis, yakni klasifikasi versi Hanafi dan versi Syafi'i18. Perbedaan dalam klasifikasi/urutan kias jali (kias aula) dan isyarah menghasilkan sejumlah perbedaan dalam keputusan hukum fiqh antara mazhab Hanafi dengan mazhab fikih lainnya (yang secara umum mengikuti klasifikasi versi Syafi'i.)

Kemudian jika dilihat segi luassempitnya cakupan pernyataan hukum

17Jasser Auda, Membumikan al Qur'amn melalui Maqasidus Syariah, Terj Rosidin dan 'Ali 'Abd el Munim, Mizan Pustaka,Bandung, 2015, h. 136.

18Ibid., h. 140-142 dalam penafsiran kebahasaan in, perbedaan teoritis terkait hubungan antar kategori yang dihasilkan menyebabkan beberapa perbedaan pendapat pada tingkatan fikih praktis. ${ }^{19}$ Dilihat dari segi luas sempitnya cakupan pernyataan hukum dalam metode linguistic ini ditemukan pernyataan hukum yang bersifat 'àmm dan khās, mutlaq dan muqayyad, haqiqi dan majazi, serta musytarak. ${ }^{20}$

${ }^{19}$ Ibid, h. 148.

20 Secara singkat, istilah-istilah tersebut mempunyai pengertian-pengertian tersendiri., yakni: (1) Kata yang bersifat 'amm merupakan kata yang menunjukkan pada jumlah yang banyak dan mencangkup apa saja yang bisa diterapkan kepadanya. Sedangkan kata yang bersifat khas merupakan implikasi berlawanan dari 'àmm. Secara sederhana dapat disimpulkan bahwa kata yang bersifat āmm merupakan kata yang belum spesifik, sedangkan kata yang bersifat khās merupakan kata yang spesifik.(2) Kata yang bersifat muthlaq merupakan kata yang tidak terkualifikasi atau pun terbatas penerapannya, sedangkan muqayyad merupakan kata yang terkualifikasi. Mutblaq juga dapat didefinisikan sebagai kata yang menunjukkan pada hakekat kata itu apa adanya tanpa memandang jumlah atau pun sifatnya. Sedangkan kata yang bersifat muqayyad merupakan kata yang menunjukkan pada hakikat kata tersebut dengan dibatasi oleh sifat, keadaan, dan syarat tertentu.(3)Kata yang bersifat majazi merupakan lafaz yang berbentuk homonim yang mencangkup apa yang diistilahkan sebagai kepalsuan atau ketidakrealistisan. Sedangkan kata yang bersifat haqiqi merupakan lafaz yang maknanya dapat diketahui dari harfiyah-nya. (4) Mushtarak 
Para fakih sepakat bahwa terma khusus itu pasti/qath'i dalam implikasinya, sehingga tidak dapat menjadi dugaan/z̧̧anni berdasarkan hepotesa apapun. ${ }^{21}$ Akan tetapi para fakih berbeda akan "kepastian" terma umum. Mazhab Hanafi menilai bahwa terma umum itu qat'i sedangkan seluruh mazhab yang lain menilai bahwa terma umum itu zhanni, sehingga dapat di takhsiskan. Perbedaan pendapat ini memiliki dampak pada nas nas yang dinilai “bertentangan". 22

Demikian pula perbedaan pendapat yang senada juga terjadi terkait cara mazhab fikih berhubungan dengan ungkapan yang "terbatas"/muqayyad) dan tidak terbatas (mutlaq). Mazhab Hanafi berpendapat muqayyad membatasi mutlaq selama masalahnya sama, sedangkan Mazhab lainnya berpendapat bahwa muqayyad

merupakan kata yang menunjukkan pada lebih dari satu makna..

21 Abu Zahrah, Ushul Fikih, h. 146, sebagaimana dikutip Jaser Audah, , h. 148.

$$
22 \text { Ibid }
$$

membatasi mutlaq selama masalah dan hukumnya sama. ${ }^{23}$

Dari segi luas-sempitnya cakupan pernyataan hukum dikenal adanya kategori perintah $(a m r)^{24}$ dan larangangan (nahy $\left.{ }^{25}\right)$ Menurut pendapat jumhur, perintah itu sendiri, apabila tidak disertai dengan petunjuk-petunjuk atau kejelasan yang memberinya makna khusus, menyatakan kewajiban atau hanya permintaan yang tegas. Tetapi hal tersebut dapat berubah apabila ada petunjuk-petunjuk lain yang dapat menarik perintah kepada mubah, sunah bahkan variasi makna lainnya. ${ }^{26}$

23 Ibid. h. 150

24 Perintah (amr) didefinisikan sebagai permintaan lisan untuk melakukan sesuatu yang keluar dari orang yang kedudukannya lebih tinggi kepada orang yang kedudukannya lebih rendah. Larangan (naby). Ibid., h. 218

25 Kata naby berarti larangan menurut bahasa, sedang menurut istilah adalah tuntutan untuk meninggalkan berbuat dari yang berkedudukan lebih tinggi ke yang berkedudukan lebih rendah. Naby ini juga menggunakan berbagai lafal dalm penunjukanya, diantaranya lafal nabyun itu sendiri, fi'il mudhori' yang diawali laa naby, dengan menunjukan bahwa suatu pernuatan adalah haram, menjelaskan ancaman bagi pelaku, dan memerintahkan untuk meninggalkan suatu perbuatan., Ibid.

$$
26 \text { Muhammad Hashim Kamali . loc. }
$$
cit., h. 180 
Dalam naby juga menimbulkan suatu tunjukan makna (dilalab an naby) antara lain : menunjukan haram, makruh, dan mengarahkan.

Metode yang berkenaan dengan ijtihad bayani ini dapat berupa metode tafsir, ta'wil, jam'u, nasakh bahkan metode tarjih dalam menyelesaikan lafazh lafazh yang diduga mengandung pengertian kontradiktif. Semua metode ini dinamakan pula metode tarjih, metode ijtibad intiqa'i. ${ }^{27}$

2. Ijtihad Qiyasi.

Ijtihad qiyasi ini adalah ijtihad yang berusaha menyberangkan hukum yang telah ada ketentuan nashnya pada masalah masalah baru yang belum ada hukumnya karena adanya kesamaan illat hukum. ${ }^{28}$

Langkah yang ditempuh untuk menemukan hukum ketika tidak ada atau tidak ditemukan teks hukumnya adalah dengan memperluas cakupan teks hukum tersebut sehingga mampu mencakup dan menjawab kasus-kasus

${ }^{27}$ Yusuf al Qardlawi, Al Ijtihad Fi al Syari'ah al Islamiyah Maqasid Asy Syari'ah an Naadharatin Tabliliyyatin fi al Ijtibad al Muashir, di terjemahkan oleh Ahmad Syathori, Ijtihad Dalam Syariat Islam, Jakarta, Bulan Bintang, 1987, h. 150.

${ }^{28}$ Dedy Supriyadi, Sejarah Hukum Islam, 2010, h. 142 yang tidak ada nasnya. Untuk melakukan perluasan cakupan teks hukum yang ada, dilakukan penyelidikan terhadap ketentuan hukum yang sudah ada di dalam teks hukum guna mengkaji dan menemukan atribut atau illat ${ }^{29}$ yang melandasi atau menjadi dasar penetapannya. Setelah ditemukannya 'illat, maka hukum tersebut diperluas hingga mencakup kasus lain sejenis yang secara harfiah tidak tercakup dalam pernyataan tekstual hukum yang ada.

Sebagian ada juga yang menyebutnya dengan ijtihad qiyasi/ijithad ta'lili/(kausasi, qiyasi) merupakan jawaban metodologis atas kasus baru yang tidak tercakup dalam redaksi nash ${ }^{30}$. Ijtihad ini ditempuh

${ }^{29}$ Definisi 'illat antara lain adalah: motif (ba'its) yang menggerakkan pemberi hukum untuk memberikan hukum. Artinya, 'illat harus mengandung alas an tersembunyi (hikmah) yang pantas menjadi tujuan bagi pembuat hukum dalam menentukan hukum. Lihat Al Amidi, al Ihkam fi Ushul al Abkam, juz 3 (Beirut: Dar al Fikr, 1996), hlm. 289. definisi yang lain adalah "sifat yang jelas, tampak, selalu ada dan sesuai dengan hukum" lihat Abu Zahrah, Ushul al Fiqh (Kairo: Dar Al Arabi, tt), hlm. 273.

30 Terdapat tiga pola (tariqat) ijtihad dalam hukum Islam yaitu bayani, ta'lili (qiyasi) dan istislahi. Ijtihad istihsani tidak dianggap sebagai pola ijtihad yang berdiri sendiri dengan alasan beberapa bagian aplikasinya 
dengan menggunakan metode qiyas bahkan menggunakan metode istihsan.

\section{a. Metode Qiyas/Kias (analogi) ${ }^{31}$}

Qiyas juga didefinisikan dengan menerangkan hukum sesuatu yang tidak ada nahṣ-nya dengan sesuatu hukum yang ada nash-nya, dengan asumsi adanya persamaan illat. ${ }^{32}$ Dalam epistemologi usul fiqih diuraikan bahwa rukun-rukun qiyas meliputi empat unsur pokok ${ }^{33}$.

Kias dinilai sah sebagai sumber legislasi sekunder oleh keempat mazhab sunni, muktazilah dan ibadi. Namun menurut Syiah Ja'fari, Zaidi, Zahiri dan beberapa mazhab Mu'tazilah menggambarkan kias sebagai legislasi berdasarkan pemikiran sehingga bersifat zhanni, dan merupakan sebuah bid'ah. Ibn Hazm mengartikulasikan posisinya dengan menunjuk kias sebagai "suatu keputusan (hukum) tanpa yang lain dalam kategori istislahi, Lihat lebih lanjut pada Muhammad Ma'ruf ad-Dawalibi, al-Madhal ila Tlm Usul al-Fiqh,(Ttp: Dar alKitab al-Jadid, 1965), h. 419.

31 Secara terminologis, terdapat dua pengertian qiyas. Mereka yang berasumsi bahwa qiyas merupakan dalil agama memaknainya sebagai "ekuivalensi antara kasus pokok dengan kasus cabang dalam causa legis yang disimpulkan dari hukum kasus pokok" atau "kesamaan kasus yang tidak disebutkan hukumnya dalam nas dengan kasus yang tidak disebutkan dalam nas menyangkut illat hukumnya."Sedangkan yang menganggapnya sebagai aktifitas mujtahid mendefinisikan sebagai "memperluas berlakunya suatu nas hingga mencakup kasus-kasus baru yang semula tidak termasuk ke dalam cakupan nas itu karena adanya persamaan causa legis"; atau dalam pandangan al-Ghazali. Al-Amidi, Al-Ihkeàm fì Usul alAbkàm,(Kairo: Dar al-Kutub al-Khidiwiyah, 1914), III:273, Al-Ghazalli, Al Mustasfa min Ilm al-Usul, (Beirut Dar al-Fikr, tt), II: 228; bandingkan dengan redaksi yang berbeda dalam id., Sifa' al-Ghalil fi Bayan al-Sabah wa alMukhl wa Masalik al-Ta'lil,(Baghdad: atba'ah al-Irsyad), hlm. 18.
32 Abdul Wahab Khalaf, op. cit., h.
33. Unsur dimaksud adalah (1)Kasus baru (furu') yang membutuhkan solusi hukum; Ia sering dimaknai sebagai persoalan yang hukumnya tidak terdapat di dalam nas, yang hukumnya disamakan kepada asl. (2)Kasus asli (as) yang ada dalam sumbersumber asli al-Qur'an, sunah dan konsensus; Ia sering dimaknai sebagai persoalan hukum yang hukumnya secara qat'i diungkap oleh nas serta mempunyai illat. Ia adalah al-maqis alaih, kepada mana furu' (al-maqis) dianalogikan. (3)Alasan. ratio legis ('llah), sifat umum yang ada pada kasus baru dan kasus asli; Ia keadaan tertentu yang [dianggap] dipakai sebagai dasar (motif) bagi hukum asl, yang mana dengan asumsi adanya kesamaan dalam sektor ini, furu' ditemukan hukumnya.(4) Norma hukum (bukm) yang dinisbatkan kepada kasus baru dan karena kesamaan antara dua kasus, yang ditransfer dari kasus lama ke kasus baru. Ia adalah ketentuan hukum yang terdapat di dalam asl, kategori apa hukum pada furu' ditemukan. Lihat Wael B. Hallaq, Sejarah Teori Hukum Islam: Pengantar Untuk Usul Fiqh Mą̧ab Sunni, ter. E. Kusnadiningrat dan Abdul Haris bin Wahid (Jakarta: RajaGrafindo Persada, 2001), h. 123. 
pengetahuan yang mantap, (hanya) mengikuti dalil dalil yang tidak pasti (zhanni) $^{34}$.

Ibn Hazm juga mengkritisai tokoh yang mendukung legitimasi kias berdasarkan ijma, berdasarkan pandangan bahwa ijmak tidak pernah terbukti. ${ }^{35}$ Beliau diikuti mazhab Zahiri secara umum mempertimbangkan pengertian literal hanya dari al Quran dan hadis untuk mempertimbangkan legitimasi dalam hukum Islam (fikih).

Ja'fari, Zaidi daaan Mu'tazilah menerima kias jika illat disebutkan dalam nash daaan bukan perkiraan (mazhab lain menyebutkan bahwa bentuk ini adalah bagian darrriii penggalian hukum berdasaaarrrkan analisis bahasa). Mazhab ibadi memasukkan kias dalam penalaran umum yang mereka sebut dengan al ra'yu. ${ }^{36}$

\section{b. Metode Istihsan}

Secara harfiyah, istibsan diartikan meminta berbuat kebaikan, yakni menghitung-hitung sesuatu dan

34 Jaser Audah , Membumikan..., 2005, , h. 159.

35 Ibid

36 Yaser Audah, Ibid, h. 160. menganggapnya kebaikan. Menurut al-Ghazali di dalam kitabnya alMustashfa juz I : 137, “istibsan adalah semua hal yang dianggap baik oleh mujtahid menurut akalnya" ${ }^{37}$.

Para imam mazhab memandang istihsan terbagi kepada beberapa pendapat. Syafi'I, Ja'fari, Zaidi dan Zahiri menilai istihsan sebagai dalil yang tidak terlegitimasi dan "dugaan". Imam al Syafi'I dan Ibn Hazm memandang istihsan sebagai pilihan berdasarkan keinginan dan suatu sumber kontradiksi.

Disisi lain Hanafi, Maliki, Ibadi, Hanbali dan Muktazilah mengesahkan istihsan sebagai sumber legislasi. ${ }^{38}$ Bahkan Imam Malik mendeskripsikan istihsan sebagai $90 \%$ pengetahuan fiqh. Beliau menganggap bahwa istihsan memuat suatu pertimbangan yang mendalam terhadap factor factor tertentu, yang seharusnya mengubah keputusan hukum yang biasanya diambilseorang fukaha. Faktor faktor ini yang disebut sebagai dasar dasar istihsan yang dapat dibagi kepada

37 Juhaya S. Praja, Ilmu Ushul Fiqih (Bandung: Pustaka Setia, 2007), h.111.

h. 168.

38 Jaser Auda, Membumikan..., 2005, 
enam kategori, yaitu nas, ijmah, keniscayaan (daruriyah), kias, kemaslahatan umum dan urf) ${ }^{39}$

\section{Ijtihad istislahiah}

Ijtihad istislabito adalah ijtihad terhadap masalah masalah yang tidak ditunjukkan hukumnya dalam secara khusus atau tidak ada nash yang serupa alasannya Penetapan hukum dilakukan berdasarkan pendekatan kemaslahatan yang menjadi tujuan hukum. ${ }^{41}$.Dengan demikian ijtihad istilahi adalah beupa upaya perenungan hati melalui proses nalar.

Corak penalaran istislahi adalah upaya penggalian hukum yang bertumpu pada prinsip-prinsip kemaslahatan yang di simpulkan dari Alquran dan hadis. Artinya kemaslahatan yang dimaksudkan disini adalah kemaslahatan yang secara umum ditunjuk oleh kedua sumber hukum terssebut. Maksudnya

${ }^{39}$ Ibid 169.

40 Menurut bahasa istishlah adalah sebagai suatu upaya penetapan hukum yang didasarkan kermaslahatan atau kebaikan (masslahah). Penggunaan istishlah harus memenuhi beberapa persyaratan, antara lain buku diukur dengan dugaan manusia, sifatnnya umum, bukan bersifat perorangan, tidak bertengtangan dengan dalil

${ }^{41}$ Dedy Supriyadi, Sejarah Hukum Islam., h. 142. kemaslahatan itu tidak dapat dikembalikan kepada suatu ayat atau hadis secara langsung baik melalui penalaran bayani atau ta'lili melainkan dikembalikan pada prinsip umum kemaslahatan yang dikandung oleh nash.

Dalam perkembangan pemikiran ushul fikih, corak penalaran istihlahi ini tampak dalam beberapa metode ijtihad,antara lain dalam metode al-mashlahah al-mursalah dan saddudz-dzari'ah.

a. Metode Maslabah Mursalab ${ }^{42}$

Maslahab Mursalab berarti kepentingan yang tidak terbatas, tidak terikat, atau kepentingan yang

${ }^{42}$ Secara etimologi mashlahah barasal dari kata shaluba di gunakan untuk menunjukan jika sesuatu atau seorang menjadi baik, tidak korupsi, benar, adil,shalih, jujur atau secara alternatif untuk menunjukan keadaan yang mengandung kebajikankebajikan tersebut. ketika dipergunakan dengan bersama preposisi Li, shaluha akan memberikan pengertian kesserasian, dalam pengertian rasionalnya maslhahah berarti sebab, cara atau suatu yang bertujuan baik. Ia juga berarti sesuatu permasalahan atau bagian dari urusan yang menghasilkan kebaikan yang dalam bahasa arab berarti "perbuatanperbuatan yang mendorong kepada kebaikan manusia. Sedang menurut istilah yaitu apa yang dipandang baik oleh akal, sejalan dengan tujuan syara' dalam menetapkan hukum, namun tidak ada petunjuk syara' yang memperhitungkan dan tidak ada pula petunjuk syara' yang menolaknya. Lihat Kutbudin Aibak, Metodologi pembaruan Hukum Islam, h. 187 dan 199. 
diputuskan secara bebas. Jika terdapat suatu kejadian yang tidak ada ketentuan syari't dan tidak ada illat yang keluar dari syara yang menentukan kejelasan hukum kejadian tersebut, kemudian ditemukan sesuatu yang sesuai dengan hukum syara, yakni suatu ketentuan yang berdasarkan pemeliharaan kemadharatan atau untuk menyatakan suatu manfaat, maka kejadian tersebut dinamakan maslahah mursalah. Tujuan utama masalib al mursalah adalah kemaslahatan, yakni memelihara dari kemadharatan dan menjaga kemanfaatannya ${ }^{43}$.

Teori masalib al mursalah ini terikat pada konsep bahwa syariah ditujukan untuk kepentingan masyarakat, dan berfungsi untuk memberikan kemanfaatan dan mencegah kemudlaratan. ${ }^{44}$ Terdapat perbedaan rumusan dikalangan ulama ketika menjelaskan merode

\footnotetext{
${ }^{43}$ Dedy Supriyadi, Sejarah Hukum Islam.,2010 h. 142

${ }^{44}$ Muhammad Muslehuddin, Filsafat Hukum Islam dan Pemikiran Orientalis, TStudi Perbandingan Sistem Hukum Islam), Terj Yudian Wahyuni Salim dkk., Yogyakarta, PT. Tiara Wacana, 1991, h127
}

ini Al-Ghazali menjelaskan bahwa menurut asalnya mashlahab itu berarti sesuatu yang mendatangkan manfaat dan menjauhkan madharat, namun hakikat dari mashlahab adalah memelihara tujuan syara'. Sedangkan tujuan syara' dalam penetapan hukum itu ada lima yaitu: memelihara agama, jiwa, akal, keturunan, dan harta. Sedang menurut Asy-syatibi mengartikan mashlahab dari dua pandangan yaitu dari terjadinya mashlabah dalam kenyataan dan dari segi tergantungnya tuntutan syara' kepada mashlabah. Dari segi terjadinya mashlahah dalam kenyataannya berarti "sesuatu yang kembali kepada tegaknya kehidupan manusia, sempurna hidupnya, tercapai apa yang dikehendaki oleh sifat syahwati dan akliyah seccara mutlak". Sedangkan dari tergantungnya tuntutan sayara' kepada mashlabah, yaitu kemaslahatan yang merupakan tujuan dari penetapan hukum syara' untuk menghasilkannya Allah menuntut manusi untuk berbuat. ${ }^{45}$

45 Ibid. h. 208 
Menurut Jaser Audah, semua mazhab menerapkan konsep kemaslahatan. Tetapi dengan namayang berbeda, tergantung terminology ijtihad masing masing mazhab. Kcuali Zahiri satu satunya mazhab yang menolak kemaslahatan dan tidak menggantinya dengan dalil alternative lainnya.

1. Syafi'i memasukkan kemaslahatan dalam konsep munasabah qias.

2. Hanafi memasukkan kemaslahatan kedalam konsep istihsan.

3. dan Zaidi meskipun mereka tidah menerima kemaslahatan tapi kecendrungan besar pada metode yuridis mereka menggunakan kemaslahatan melalui dalil akal setelah $\mathrm{Al}$ Qur'an Sunnah dan Ijma ${ }^{46}$.

b. Metode Saddudz-dzara' ${ }^{47}$

\footnotetext{
${ }^{46}$ Jaser Audah, Membumikan..., 2005., h. 168

47 Secara harfiah Saddudz-dzara'i terdiri atas dua kata yakni sad yang berarti penghalang atau sumbat dan dzariah yang artinya jalan. Oleh karenanya Saddudz-dzara'i
}

Metode Saddudz-dzara'i ini dikenal juga dengan metode pemblo kiran sarana yang menghantarkan kepada mudlarat, yang dinikai para fuqaha sebagai sumber legislasi khususnya Maliki. Tapi mayoriratas mereka menyebutkan bahwa Saddudzdzara'i ini bukanlah dalil yang mandiri, tetapi memasukkan kedalam kemaslahan. ${ }^{48}$ Metode ini tidak hanya bersifat menghindarkan kerusakan namun dzari'ah juga untuk menarik kemanfaatan, kemanfaatan dan kerusakan inilah yang menjadi parameter prinsip digunakannya dzariah. Jika kerusakan lebih besar dari manfaatnya maka hukum terhadap hal itu melalui dzari'ah akan menjadi dilarang.

Ibnu Qayim berpendapat bahwa apam yang dilarang sebagai

dimaksudkan sebagai menghambat atau menyumbat semua jalan yang menuju kepada kerusakan atau maksiat. Tujuan penetapan melalui metode ini adalah untuk memudahkan tercapainya kemaslahatan dan jauh kemungkinan memudahkan terjadinya kerusakan. Metode ini disebut sebagai metode preventif mencegah sesuatu sebelum terjadinya suatu yang tidak diinginkan. Abdul Ghofur Anshori dan zulkarnaen harahap, Hukum Islam Dinamika dan perkembangannya di indonesia, (Yogyakarta: Total Media, 2008), h.. 191 2005., h. 171. 
Jurnal Syariah: Jurnal Ilmu Hukum dan Pemikiran

suatu tindakan preventif, yaitu Sadd al Zara'I, menjadi boleh dilihat dari segi kebutuhan masyarakat, tetapi apa yang dilarang dengan tujuan tertentu tidak dapat diperbolehkan kecuali karena terpaksa. ${ }^{49}$

\section{Kesimpulan}

Setelah melakukan telaah mendalam, maka penulis menemukan beberapa simpulan:

1. Ulama sepakat bahwa al Quran dan al Hadis merupakan sumber ajaran sekaligus sumber hukum Islam yang utama dan paling utama, namun kedua sumber tersebut tidak selamanya tegas dan terperinci oleh karena itu dibutuhkan ijtihad untuk menemukan hukum yang bersumber dari keduanya.Dalam upaya menemukan hukum dan penerapan hukum para pengali hukum Islam seyogianya bertitik tolak dari prinsip kemaslahatan dengan metode yang telah ditawarkan h.148.
Metode Penemuan Hukum..143-159 Yusna Zaidah

oleh para pendahulu yang ahli dibidangnya.

2. Metode penemuan hukum merupakan thuruq al-istinbath yaitu cara-cara yang ditempuh seorang mujtahid dalam mengeluarkan hukum dari dalilnya, baik dengan menggunakan kaidah-kaidah bahasa (lingkuistik) maupun dengan menggunakan kaidahkaidah Ushuliyah lainnya.

3. Bentuk metode hukum Islam tidak dapat dipisahkan dengan objek kajian dan orientasi model metode ijtihad tersebut. Kaum usuliyyun (para teoritisi hukum Islam) walaupun berbeda istilah merumuskan tiga teori/metode penemuan hukum Islam, pertama teoro/metode interpretasi kebahasaan, Metode Kausasi (at ta'lili/istislabiah) adalah upaya penggalian hukum terhadap masalah masalah yang tidak ditujukkn hukumnya dalam nash secara khusus atau tidak ada nash pada masalah yang serupa alasannyakedua metode metode interpretasi yang 
didasarkan pada kesamaan (illat) hukum dan terakhir metode penyelarasan/ sinkronisasi (at Taufiq).

\section{Daftar Pustaka}

A. Djazuli, Fiqh Siyasah, (Bandung:

Prenada Media, 2003).

-------------, , Ilmu Fiqh Penggalian,

Perkembangan dan Penerapan

Hukum Islam, Cet. 5, Edisi

Revisi, Jakarta, Prebada

Media, 2005)

Abd al-'Azīm al-Dîb, Fiqh Imām

Haramayn, (Qatar: Idārat Uhyā'

al-Turāth al-Islāmî, 1985).

Abu Zahrah, Ushul al Fiqh (Kairo:

Dar Al Arabi, tt)

Ahmad Azhar Basyir, Pokok-Pokok

Persoalan Filsafat Hukum Islam,

(Yogyakarta, UII Pres, 1984)

Al Amidi, al Ihkam fi Ushul al Abkam,

juz 3 (Beirut: Dar al Fikr, 1996),

Al-Ghazalli, Al Mustasfa min Ilm al-

Usul, (Beirut Dar al-Fikr, tt).

Al-Syatibi, Al-Muwafaqat fi Ushul alAbkam, Jilid III,. (t.t.: Dar alFikr, t.th)

Al Yasa Abu Bakar, Metode Istislabiah, Pemanfatan Ilmu Pengetabuan dalam Ushul Fiqh), Kencana, Jakarta, 2016

Duski Ibrahim, Metode Penetapan

Hukum Islam Membongkar

Konsep Al-Istigra Al-Ma'nawi

Asy-Syatibi, (Yogyakarta: Ar-

Ruzz Media, 2008)

Faturrahman Djamil. Filsafat Hukum

Islam, Jakarta : Logos Wacana

Ilmu, 1999

Jazim Hamidi, Hermenentika Hukum,

Teori Penemuan Hukum Baru

Dengan Interprestasi Teks,(

Yogyakata, UII Pres, 2004)

Khalid Mas'ud, Islamic Legal Philosophy: A Study of Abu Ishak Al-Syatibi's Life and Thanght.

Delhi : International Islamic

Publishers, 1989

Kutbudin Aibak, metodologi pembaruan

Hukum Islam, (Yogyakarta,

Pustaka Pelajar, 2008)

Louay Safi, Ancangan Metodologi Alternatif, Sebuah Refleksi Perbandingan Metode Penelitian Islam dan Barat, ter. Imam Khoiri (Yogyakarta: Tiara Wacana, 2001)

Muhammad 'Abed al-Jabiri, Bunyah al 'Aql 'Arabi: Dirasah Tabliliyah Naqdiyah li Nizami al-Ma'rifah fi 
al-Saqafah al-Arabiyah,. (Beirut: al-Markaz al-Saqafi al-Arabi, 1993)

-------------,Takwin al-'Aql alArābì, (Beirut: al-Markaz alSaqafī al-Arabī, 1991)

Muhammad Abu Zahrah, Ushul Fiqih, ter. Saefullah Ma'sum (Jakarta: Pustaka Firdaus, 1999)

Muhammad Hashim Kamali, Prinsip dan Teori-Teori Hukum Islam (Usul al-Fiqh), ter. Noorhaidi (Yogyakarta: Pustaka Pelajar, 1996)

Muhammad Ma'ruf ad-Dawalibi, alMadhal ila Tlm Usul alFiqh,(Ttp: Dar al-Kitab alJadid, 1965)

Muhammad Roy, Ushul Fiqh Madzhab Aristoteles:

Pelacakan Logika Aristoteles dalam Qiyas Ushul Fiqih,cet. 1 (Yogyakarta: Safiria Insania Press, 2004)

N.J. Coulson, A Hiṣtory of Ișlamic Law, (Edinburg: Edinburg University Press, 1978)

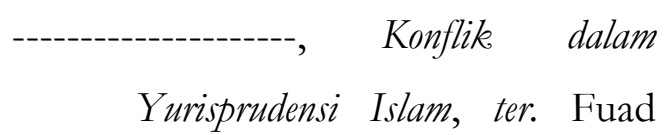

(Yogyakarta: Navila, 2001)
Syamsul Anwar, "Teori Konformitas dalam Metode Penemuan Hukum Islam Al Gazzali" dalam Antologi Studi Islam; Teori dan Metodologi, oleh M. Amin Abdullah, dkk (ed.) (Yogyakarta: Sunan Kalijaga Press, 2000).

Shubhi Mashmashani. Falsafatu alTasyri fi al Islam, t.t. : Dar alKasy Yayaf, 1952.

Wael B. Hallaq, Sejarah Teori Hukum Islam: Pengantar Untuk Usul Fiqh Mą̧ab Sunni, ter. E. Kusnadiningrat dan Abdul Haris bin Wahid Jakarta: RajaGrafindo Persada, 2001)

Yudian W. Aswin, "Maqāsìid alShariah sebagai Doktrin dan Metode”, Jurnal Al-Jami'ah IAIN Sunan Kalijaga Yogyakarta. No. 58, tahun 1995 